Bushnell, jun. (Smithsonian Miscell. Collect., 99, 15 ; 1940 ) it is recorded that stone artefacts, fragments of steatite vessels and small bits of earthenware were exposed during removal of the top soil. Although some specimens were obviously older than others, no determination of age was possible in the absence of stratification. Nor was it possible to mark the extent of the settlement; but quantities of flakes of various types and fractured pebbles indicated the existence of a workshop. The types of artefact included flake-knives and scrapers, projectile points, several forms of edged implements, axe-like implements, hammerstones and possibly pestles. Two Folsom points have been found on the site mingled with the other material.

This is the first occasion, so far as is known, on which the Folsom point has been found in the eastern States in association with other material or on a settlement site, though Folsom points of the Eastern type, which is not identical in all details with that of the south-western States, have been found sporadically in Virginia and elsewhere. The specimens from the Mons site may be regarded as clinching the argument for an eastward extension of Folsom man associated with an evolving industry, conditioned at times by the necessary employment of a refractory material. That the nature of the stone and not ignorance of the characteristic technique is responsible for the absence of the groove in the chert points from the Mons site is shown by the occurrence there of flakes of jasper, such as would be produced in the manufacture of a typical point of that material, which has been found no more than two miles away.

\section{Agricultural System of the Argentine}

THE Imperial Bureau of Pastures and Forage Crops, Aberystwyth, has recently published a bulletin on "The Grasslands of the Argentine and Patagonia" (Bull. 30. 2s. 9d.). The author, W. Davis, has himself made an extensive tour of South America, and his account contains much of interest to the general reader as well as to the grassland specialist. Patagonia is chiefly a sheep ranching country, carrying a vegetation of open tussock grassland in the south, and shrub steppe in the central and northern regions. In the Argentine proper, cattle are more important than sheep and, compared with Patagonia, farming is much more intensive. As a result, the native flora has been largely replaced by exotic species of both grasses and legumes.

One of the most interesting features of this intensive farming is the practice of fattening cattle on lucerne in the La Plata region. The temporary ley is the basis of this form of husbandry, together with the use of cereal crops for out-of-season grazing. Much of the land is held by companies and by individuals who are fattening cattle on large holdings (Estancias), and is worked on a share farming system. The farmer cultivates and crops the land, sharing the crop with the landowner on an agreed basis. After a run of cereal crops, it is a condition that the land must be laid down to lucerne, at which juncture the farmer moves on to another holding, and the owner receives his land back carrying the requisite crop for his cattle. It is suggested that a modification of this system might profitably be used in parts of Great Britain. The bulletin concludes with an interesting account of the frigorifico at. Buenos Aires, where killing of the cattle and utilization of every part of the carcasses are carried out in a most efficient manner.

\section{The Nigerian Forester}

THE idea of issuing a journal in Nigeria or for West Africa generally on the lines of the Indian Forester was mooted several years ago. Last year saw a realization when two numbers of the Nigerian Forester were published in July and November. The editor appears to be somewhat diffident about the appearance of a new publication in war-time. The paper devoted to its publication, however, is very far from being wasted, for some of the articles appearing in the first number are both timely and of interest. With one exception, where the exotic trees of the Cameroons are dealt with by D. R. Rosevear, the articles in the first number deal with either Northern or Southern Nigeria and present a wide variety of problems. In the second number, in addition to some general articles such as "Termites and Soil Fertility", "Work in the Veterinary Department, Nigeria", and "Some Applications of Grassland Ecology", subjects such as "The Gold Coast Timber Industry" and "First Impressions of Forestry in Sierra Leone" are dealt with.

Perhaps of wider interest, though somewhat sad, is the announcement that the Nigerian Forester is to be replaced by another publication on the same lines but with a wider purview, entitled Frarm and Forest. This publication will be devoted to the discussion of land use problems in West Africa from the point of view not only of the forester but also of agricultural, veterinary and other workers interested in the manifold aspects of rural economy. It will thus have a wider public and should get over the financial difficulty which a specialized journal issued by a small Government Department always has to face.

\section{Underground Gasification of Coal in the U.S.S.R.}

The "Russia Today" Press Service has issued a statement of the progress of work on this problem during the last fow years in the U.S.S.R. It is recalled that Mendeléeff envisaged this method of füel treatment, and about a generation ago Sir William Ramsay suggested the initiation of research thereon in Great Britain. In the U.S.S.R., however, the first practical work was begun in 1933 on the gasification of the coal in the seam. This is reached by two shafts connected by a tunnel cut through the seam itself. The coal is gasified by a blast of air or oxygen and steam blown down one shaft while the hot gas produced is collected from the up-cast shaft. This method necessitates the labour of miners to sink the shafts and to tunnel the seam before gasification can begin. In a new installation in the Donetz coalfield, the seam will be reached by bore holes so that no underground work will be necessary. Last 